\title{
Pt-Sn Catalysts for Ethanol Oxidation in Fuel Cell Systems: Effect of reducing choice
}

\author{
F.E. LÓPEZ-SUÁREZ ${ }^{1}$, C. T. CARVALHO-FILHO ${ }^{1}$, A. BUENO-LÓPEZ², K. I. B. EGUILUZ ${ }^{1}$, G. \\ R. SALAZAR-BANDA ${ }^{1}$
}

1 Universidade Tiradentes, Instituto de Tecnologia e Pesquisa / Laboratório de Eletroquímica e Nanotecnologia.

${ }^{2}$ Universidad de Alicante, Departamento de Quimica Inorganica / MCMA E-mail para contato: franzedwin@gmal.com

\begin{abstract}
RESUMO - The Pt-Sn/C electrocatalysts performance greatly depends on preparation procedures and $\mathrm{Pt}: \mathrm{Sn}$ atomic ratios. Here, we synthesized a series of $\mathrm{Pt}-\mathrm{Sn} / \mathrm{C}$ nanoparticle catalyst with a $20 \%(\mathrm{w} / \mathrm{w})$ metal load $(\mathrm{Pt}+\mathrm{Sn})$ on carbon black with a nominal Pt:Sn atomic ratio of 3:1, $\mathrm{NaBH}_{4}$ (A) using and formic acid (B) as reducing agents aiming to study the effect of preparation method on chemical-physical properties of electrocatalyst. The onset potential of ethanol electrooxidation over $\mathrm{Pt}-\mathrm{Sn} / \mathrm{C}$ catalyst was shifted by about $0.03 \mathrm{~V}$ negatively in comparison with that over $\mathrm{Pt} / \mathrm{C}$ catalysts. At lower potential than 0.4 $\mathrm{V}, \mathrm{Pt}-\mathrm{Sn} / \mathrm{C}-(\mathrm{A})$ shows the highest current density value, while at potentials higher than $0.4 \mathrm{~V}$, the $\mathrm{Pt}-\mathrm{Sn} / \mathrm{C}-(\mathrm{B})$ catalyst has the highest activity. The difference of activity of Pt$\mathrm{Sn} / \mathrm{C}-(\mathrm{A})$ and $\mathrm{Pt}-\mathrm{Sn} / \mathrm{C}-(\mathrm{B})$ catalyst is attributed to different grade of interaction between platinum and tin for bimetallic catalysts produced from the preparation method and capacity of reduction of reducing agent.
\end{abstract}

\section{INTRODUÇÃO}

Fuel cells employing alcohols directly as fuel - direct alcohol fuel cells - are attractive as power sources for mobile, stationary and portable applications. The alcohol is fed directly without any previous chemical modification and it is oxidized at the anode while oxygen is reduced at the cathode. Among alternative fuels, ethanol is a promising candidate since it can be readily produced from renewable sources, further is less toxic than methanol (Antolini, 2007).

The high activity and stability of Pt makes it a suitable electrocatalyst for electrooxidation of many small organic molecules. However, in the case of ethanol, the formation on its surface of strongly adsorbed species coming from its dissociative adsorption poisoning the Pt anode catalysts. Efforts to mitigate the poisoning of $\mathrm{Pt}$ have been concentrated on the addition of co-catalysts, particularly tin to platinum (Antolini and Gonzalez, 2011). In this context, it is of great importance to develop anode catalysts for ethanol electrooxidation with greater activity than pure Pt to improve the performance of a direct ethanol fuel cell.

The activity-promoting effect of $\mathrm{Sn}$ on $\mathrm{Pt}$ catalysts has been controversial, and diverse viewpoints have focused on the effects of $\mathrm{Sn}$ on $\mathrm{Pt}$ to improve catalytic activity. So, the $\mathrm{Pt}-\mathrm{Sn} / \mathrm{C}$ 


\section{9 a 22 de outubro de 2014 \\ Florianópolis/SC}

electrocatalyst performance greatly depends on preparation procedures and Pt:Sn atomic ratios (Colmati et al, 2005).

Therefore, the goal of this work was synthesized a series of Pt- $\mathrm{Sn} / \mathrm{C}$ nanoparticle catalyst with a $20 \%(\mathrm{w} / \mathrm{w})$ metal $(\mathrm{Pt}+\mathrm{Sn})$ on carbon black with a nominal Pt:Sn atomic ratio of 3:1, using $\mathrm{NaBH}_{4}$ or formic acid as reducing agents aiming to study the effect of preparation method on chemical physical properties of electrocatalyst towards electrooxidation of ethanol.

\section{EXPERIMENTAL}

\subsection{Preparation and characterization of electrocatalysts.}

The electrocatalysts Pt-Sn/C nanoparticle catalyst with a $20 \%(\mathrm{w} / \mathrm{w})$ metal load $(\mathrm{Pt}+\mathrm{Sn})$ on carbon black with a nominal Pt:Sn atomic ratio of 3:1, were prepared by a deposition process using $\mathrm{NaBH}_{4}$ and formic acid $\left(\mathrm{CH}_{2} \mathrm{O}_{2}\right)$ as the reducing agents.

The electrocatalyst $\mathrm{Pt}-\mathrm{Sn} / \mathrm{C}-$ (A) synthesized by co-precipitation of both metals (Kaplan et al., 2011). The carbon support was added to $0.4 \mathrm{M} \mathrm{HCl}+\mathrm{SnCl}_{2} \cdot 3 \mathrm{H}_{2} \mathrm{O}$ and $\mathrm{H}_{2} \mathrm{PtCl}_{6} \cdot 6 \mathrm{H}_{2} \mathrm{O}$ solutions and stirred for 2 hours. An ammonia solution was added while stirring until $\mathrm{pH} 11$ was achieved, and an aqueous solution of $\mathrm{NaBH}_{4}$ added to force the reduction and precipitation of the $\mathrm{Pt}$ and/or $\mathrm{Sn}$ metal cations. The mixture was stirred for $2 \mathrm{~h}$, the powder recovered by filtration, washed with ultrapure water until no chloride ions could be detected and dried at $60^{\circ} \mathrm{C}$ by $12 \mathrm{~h}$. The powder was washed with $0.5 \mathrm{M} \mathrm{H}_{2} \mathrm{SO}_{4}$ at $60{ }^{\circ} \mathrm{C}$ for $4 \mathrm{~h}$ to remove unstable moieties from the surface and yield a stable catalyst.

To prepare the electrocatalyst $\mathrm{Pt}-\mathrm{Sn} / \mathrm{C}-(\mathrm{B})$ an appropriate mass of carbon powder substrate $\mathrm{N} 330$ (Alfa Aesar), $75 \mathrm{~m}^{2} \mathrm{~g}^{-1}$ was suspended in $2 \mathrm{~mol} \mathrm{~L}^{-1}$ formic acid ( $\left.\mathrm{HCOOH}\right)$ solution and the suspension was heated to $90^{\circ} \mathrm{C}$ (Colmati et al., 2005). Chloroplatinic acid and a tin chloride solutions (Sigma Aldrich, purity $>98 \%$ ), were slowly added to the carbon suspension. The suspension was left to cool at room temperature and the solid filtered and dried in an oven at $60^{\circ} \mathrm{C}$ by $12 \mathrm{~h}$.

The crystalline structure was determined by X-ray diffraction (XRD) in a Seifert powder diffractometer using $\mathrm{CuK} \alpha$ radiation $(0.15418 \mathrm{~nm})$. The diffractograms were registered at $2 \theta$ angles from 20 to $80^{\circ}$, with a step of $0.02^{\circ}$ and a time per step of 3 seconds Transmission electron microscopy images (TEM) were obtained using a JEOL (JEM-2010) microscope at $200 \mathrm{kV}$.

\subsection{Electrochemical measurements.}

Electrochemical measurements were performed at room temperature using an Autolab Model PGSTAT 30 potentiostat/galvanostat. Experiments were carried out in a glass cell (one compartment) using a conventional three-electrode configuration (half-cell), using a boron-doped diamond (BDD) electrode as substrate for the electrocatalytic materials. The catalyst ink was prepared by mixing $8 \mathrm{mg}$ 
of catalyst powder, $1 \mathrm{ml}$ water (Milli-Q system) and $200 \mu \mathrm{Nafion}{ }^{\circledR}$ solution (5 wt.\% Aldrich solution), which was dispersed in an ultrasonic bath. The catalyst suspension $\left(3.6 \mu \mathrm{g} \mathrm{metal} / \mathrm{cm}^{2}\right)$ was transferred with an injector to a BDD electrode and the electrode heated at $60^{\circ} \mathrm{C}$ for $10 \mathrm{~min}$. The reference system consisted of a hydrogen electrode in the same solution (HESS) connected by a Luggin capillary, and a Pt coil $\left(0.5 \mathrm{~cm}^{2}\right)$ was used as the counter-electrode.

Electrochemical activity tests were performed in aqueous $0.5 \mathrm{M} \mathrm{H}_{2} \mathrm{SO}_{4}$ solutions containing 0.5 $\mathrm{M} \mathrm{C}_{2} \mathrm{H}_{5} \mathrm{OH}$ at room temperature. Cyclic voltammetry experiments were performed between 0.0 and $0.8 \mathrm{~V}$ (vs HESS) until stationary responses were obtained, then two voltammetric cycles were performed between 0.0 and $1.3 \mathrm{~V}$ (vs HESS) at a scan rate of $0.02 \mathrm{~V} \mathrm{~s}^{-1}$ to evaluate the behavior of each electrocatalyst. Chronoamperometric experiments was performed at $0.6 \mathrm{~V}$ (vs HESS) and anode polarization curves obtained between 0.2 and $0.8 \mathrm{~V}$ (vs HESS) in the potentiostatic mode, with all data points obtained after $200 \mathrm{~s}$ of polarization at each potential

\section{RESULTS AND DISCUSSION}

\subsection{Characterization of electrocatalysts}

X-ray powder diffraction patterns are shown in Figure 1. X-ray diffractograms showed two bands at $26^{\circ}$ and $44^{\circ}$, assigned to the (002) and (100) planes of the graphite-like crystalline structure of the carbon support, respectively. The diffraction peaks at $2 \theta$ of $39.9^{\circ}, 46.5^{\circ}$ and $67.8^{\circ}$ were assigned to the Pt (111), (200), and (220) planes, respectively (see JCPDS 04-0802 reference included in Figure 1), which represented the typical character of a polycrystalline Pt-face centered cubic (fcc). Peaks of pure Sn nor its oxides were found, in spite of their presence in a small amount or in an amorphous form cannot be ruled out.

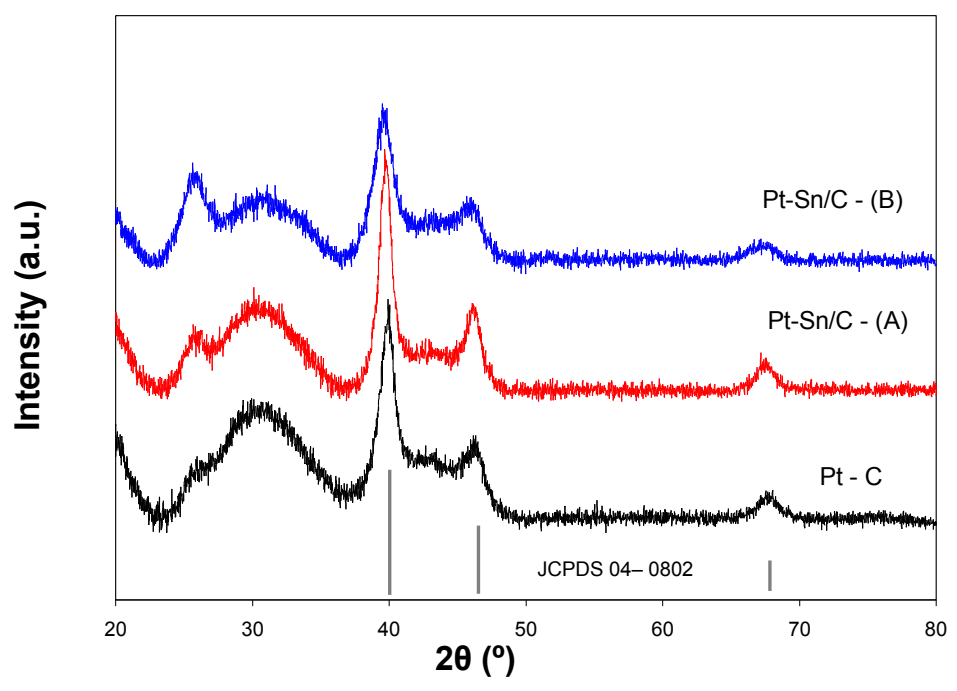

Figure 1. X-ray diffractograms of catalyst. 
A little shift of the reflections peaks compared to that of $\mathrm{Pt} / \mathrm{C}$ catalyst are displayed, visibly, for ( $\left.\begin{array}{lll}1 & 1 & 1\end{array}\right)$ and $\left(\begin{array}{lll}2 & 2 & 0\end{array}\right)$ plane. Platinum and tin form five bimetallic intermetallic phases, $\mathrm{Pt}_{3} \mathrm{Sn}, \mathrm{PtSn}$, $\mathrm{Pt}_{2} \mathrm{Sn}_{3}, \mathrm{PtSn}_{2}$, and $\mathrm{PtSn}_{4}$, of which $\mathrm{Pt}_{3} \mathrm{Sn}$ and $\mathrm{PtSn}$ are congruently melting compositions. These intermetallic phases are distinguished by distinct crystalline structures (Kuznetsov et al, 1986). So, the shift of the fcc Pt peaks of Pt-Sn/C catalysts to lower angles than pure Pt should reveal the formation of a solid solution between $\mathrm{Pt}$ and $\mathrm{Sn}$ due to the incorporation of $\mathrm{Sn}$ in the fcc structure of $\mathrm{Pt}$ as a function of preparation method. The Pt (220) peak broadening was used to calculate the average particle size according to the Scherrer's equation. Pt-Sn particles with an average size in the range of $5.0-7.2 \mathrm{~nm}$ were prepared with the procedure used.

TEM micrographs are shown in Figures 2a-b for $\mathrm{Pt}-\mathrm{Sn} / \mathrm{C}-(\mathrm{A})$ and $\mathrm{Pt}-\mathrm{Sn} / \mathrm{C}-(\mathrm{B})$ electrocatalysts, respectively. The TEM image indicates that the black color small Pt particles have homogeneous particle distribution on the carbon support. Small aggregates were also seen on $\mathrm{Pt}-\mathrm{Sn} / \mathrm{C}$ - (A) electrocatalyst. This aggregation might be possible because to preparative process as well as lower surface area black carbon used as support. The final forms of particles depend on the reducing agent used due to different capacity of each reducing agent, $\mathrm{NaBH}_{4}>\mathrm{HCOOH}$.
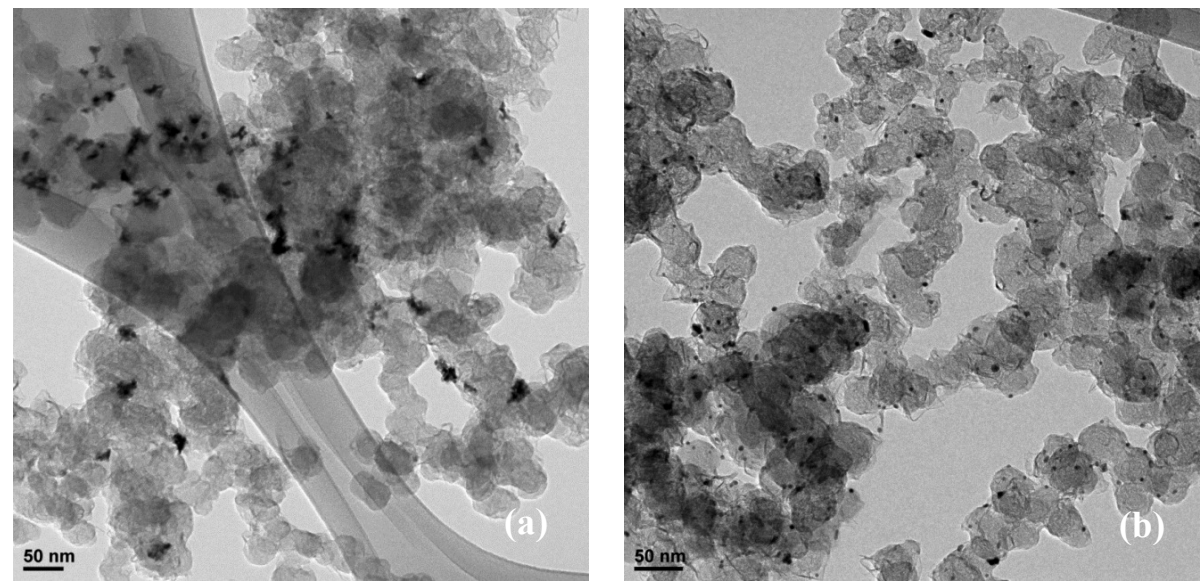

Figure 2. TEM micrographs for (a) $\mathrm{Pt}-\mathrm{Sn} / \mathrm{C}-(\mathrm{A})$ and (b) $\mathrm{Pt}-\mathrm{Sn} / \mathrm{C}-(\mathrm{B})$.

\subsection{Electrocatalysts electrochemical characterization.}

Figure 3 shows cyclic voltammograms obtained in $0.5 \mathrm{M} \mathrm{H}_{2} \mathrm{SO}_{4}$ at a scan rate of $0.02 \mathrm{~V} \mathrm{~s}^{-1}$ (all catalysts). The profiles indicate the typical behavior regarding the hydrogen and the oxide regions of $\mathrm{Pt}$ in the materials in acid solutions (Stevens et al, 2005). The adsorption - desorption of hydrogen between $0.05-0.4 \mathrm{~V}$ is displayed for all catalyst. However, this zone has little definition for $\mathrm{Pt} / \mathrm{C}$ catalysts prepared. The large value of the double-layer charging current $(0.4-0.8 \mathrm{~V})$ is observed, which is attributed to the presence of tin oxides on the particles surface that increases the electrode capacitance (Stevens et al, 2005). 
The electrocatalytic activities of the different catalysts during the oxidation of ethanol were compared by cyclic voltammetry, chronoamperometric and quasi-steady-state polarization measurements at room temperature. Figure 4 shows the anodic scan of the cyclic voltammetries for the different electrocatalysts. The profiles show similar electrocatalytic activity at lower potential (until 0.3), while, a better performance is observed for the $\mathrm{Pt}-\mathrm{Sn} / \mathrm{C}$ - (B) catalyst at higher potentials. Sn significantly enhances the electrochemical activity of platinum to ethanol electrooxidation. Cyclic voltammetric results show that $\mathrm{Pt}-\mathrm{Sn} / \mathrm{C}$ - (B) catalyst is a more suitable electrocatalyst for ethanol oxidation in comparison with other catalyst, because the energy necessary for ethanol electrooxidation is lower and produces higher current.

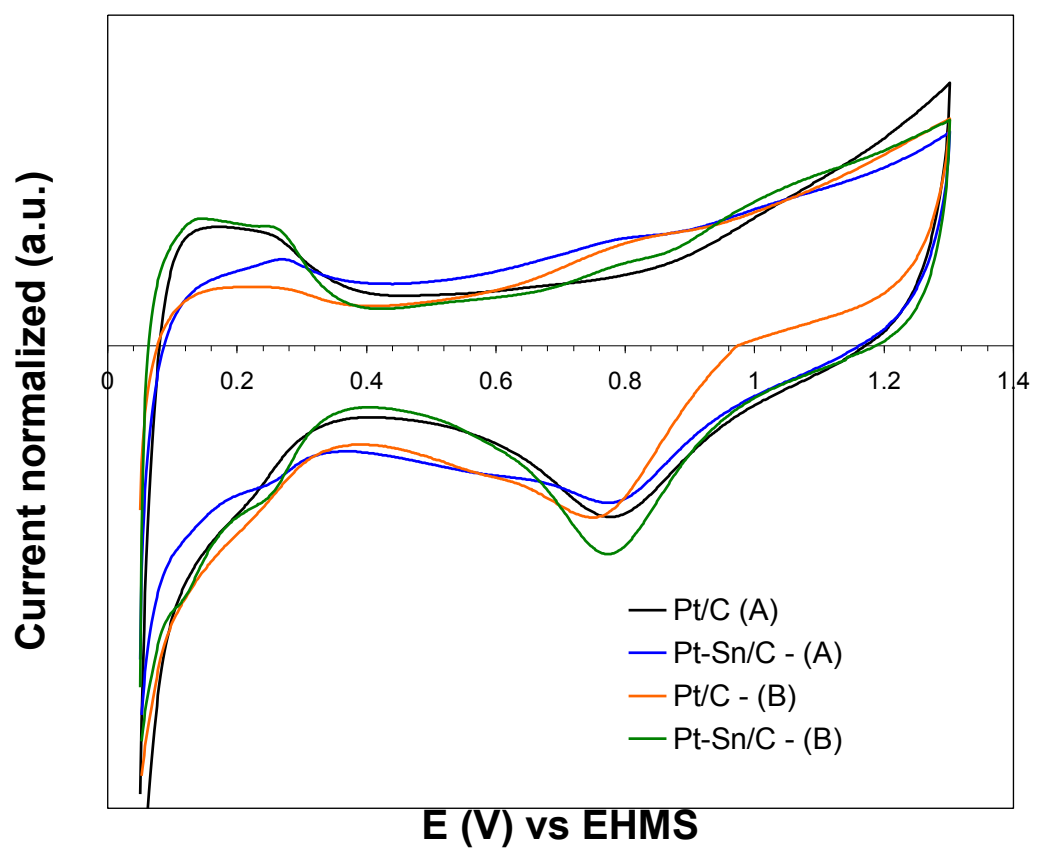

Figure 3. Cyclic voltammetry curves recorded for the electrocatalysts in $0.5 \mathrm{M} \mathrm{H}_{2} \mathrm{SO}_{4}$ electrolyte.

Chronoamperometric curves were recorded at 0.6 V (vs. RHE) (Figures 5) to compare the catalytic activity of the anode catalysts. During the first seconds, there was a sharp decrease in the current density followed by a slow decrease in the current density values for longer time periods, and a steady-state current observed for all catalysts after ca. $200 \mathrm{~s}$. This test corroborated the higher activity of the $\mathrm{Pt}-\mathrm{Sn} / \mathrm{C}$ - (B) catalyst in comparison to other catalyst at higher potential.

Figure 6 shows anode polarization curves. The onset potential of ethanol electrooxidation over $\mathrm{Pt}-\mathrm{Sn} / \mathrm{C}$ catalyst are shifted by about $0.03 \mathrm{~V}$ negatively in comparison to that over Pt-C catalysts. At lower potential than $0.4 \mathrm{~V}, \mathrm{Pt}-\mathrm{Sn} / \mathrm{C}-(\mathrm{A})$ show highest current density, while at $0.4 \mathrm{mV}$ and on, the $\mathrm{Pt}-\mathrm{Sn} / \mathrm{C}-(\mathrm{B})$ catalyst has highest activity. The difference of activity of $\mathrm{Pt}-\mathrm{Sn} / \mathrm{C}-(\mathrm{A})$ and $\mathrm{Pt}-\mathrm{Sn} / \mathrm{C}-$ (B) catalyst is attributed to different grade of interaction between platinum and tin for bimetallic catalysts produced from preparation method, specifically by capacity of reduction of reducing agents. 


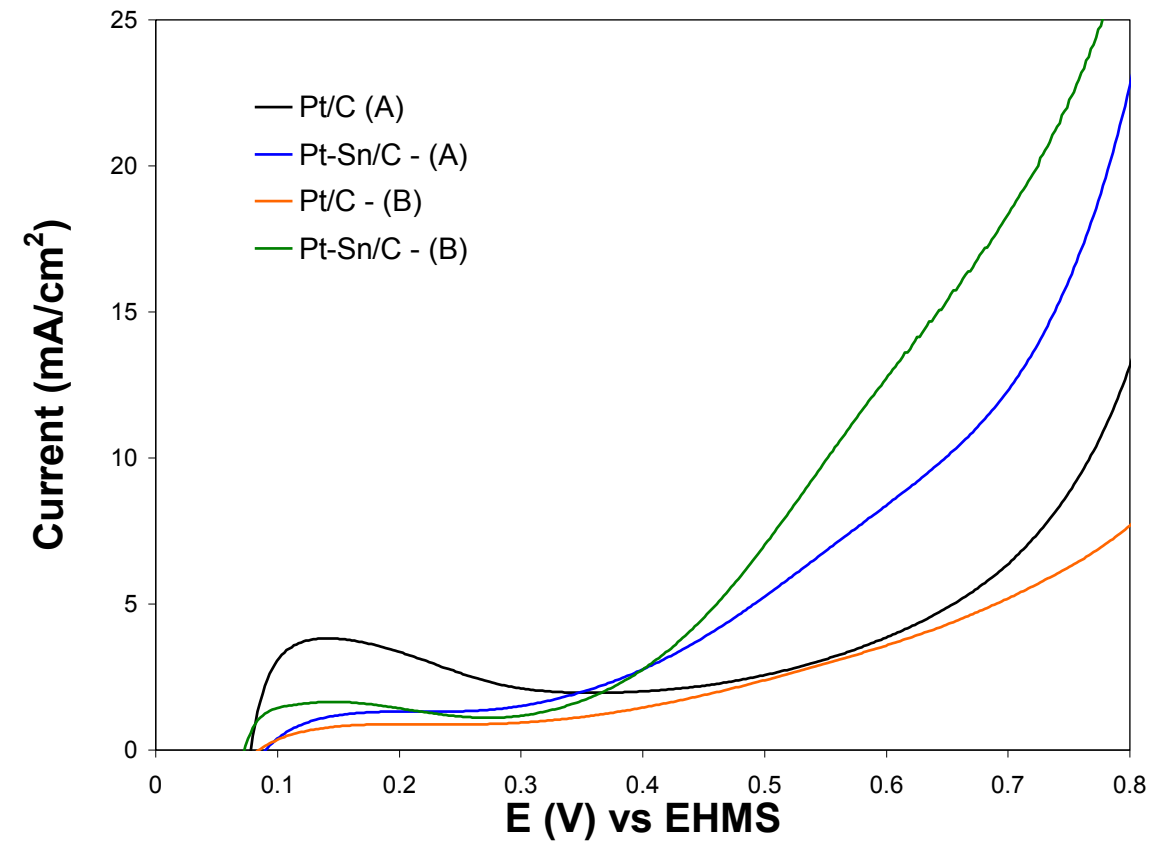

Figure 4. Cyclic voltammetry curves recorded for the electrocatalysts in $0.5 \mathrm{M} \mathrm{C}_{2} \mathrm{H}_{5} \mathrm{OH} / 0.5 \mathrm{M}$ $\mathrm{H}_{2} \mathrm{SO}_{4}$.

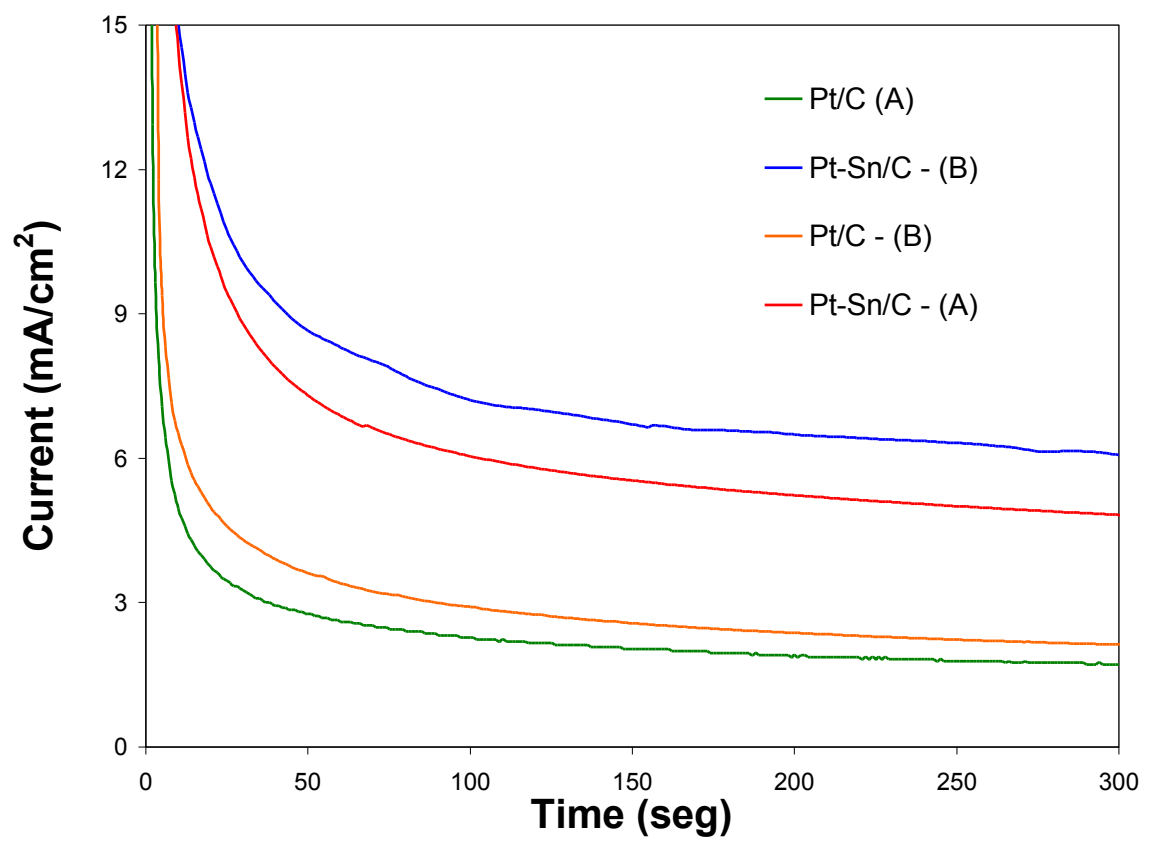

Figure 5. Chronoamperometric experiments for the electrocatalysts in $0.5 \mathrm{M} \mathrm{C}_{2} \mathrm{H}_{5} \mathrm{OH} / 0.5 \mathrm{M} \mathrm{H}_{2} \mathrm{SO}_{4}$. 


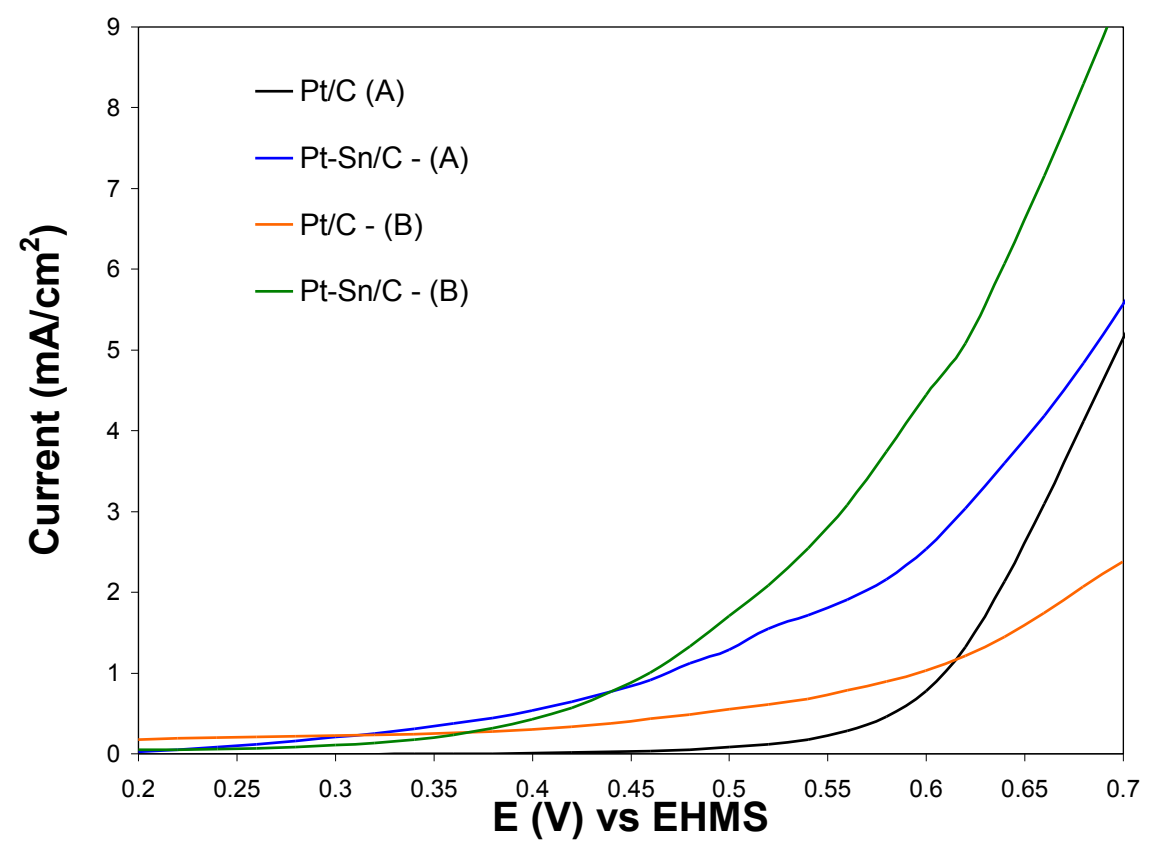

Figure 6. Anodic polarization profiles for the electrocatalysts in $0.5 \mathrm{M} \mathrm{C}_{2} \mathrm{H}_{5} \mathrm{OH} / 0.5 \mathrm{M} \mathrm{H}_{2} \mathrm{SO}_{4}$.

From results obtained in this study can be conclude the use of diferent reducing agents $\left(\mathrm{NaBH}_{4}(\mathrm{~A})\right.$ using and formic acid (B)) have influence on the physical-chemical properties of catalyst and electrocatalityc activity. The negative potential shift of the beginning of ethanol oxidation on Pt-Sn catalysts could be attributable to both the synergetic role of tin in platinum catalytic activity (promoted mechanism) (Wang et al, 1996) to ethanol electrooxidation and the structural modification of Sn to Pt (intrinsic mechanism) (Christensen et al, 1993). The results present that choice of reducing agent in catalyst preparation have influence in the electro-oxidation ethanol, where, the Pt-Sn/C - (B) prepared using formic acid as reducing agent show a more suitable electrocatalyst for ethanol oxidation at potential higher than $0.45 \mathrm{~V}$.

\section{CONCLUSIONS}

In this work was synthesized a series of Pt- $\mathrm{Sn} / \mathrm{C}$ using $\mathrm{NaBH}_{4}$ and formic acid as reducing agents and the following results were found:

- Pt-Sn catalysts synthesized for two methods are suitable electrocatalyst for ethanol oxidation in comparison with catalyst without tin.

- The structural modification of $\mathrm{Sn}$ to $\mathrm{Pt}$ decreases the energy necessary for ethanol 
electrooxidation in different way for methods studied.

- $\quad$ Pt-Sn catalysts formed a solid solution. Different amount of alloyed Sn in the Pt-Sn catalysts as a function of the synthesis method.

\section{ACKNOWLEDGEMENTS}

The authors thank the Brazilian National Council of Technological and Scientific Development-CNPq (grants: 303630/2012-4, 402243/2012-9 and 310282/2013-6) for the scholarships and financial support for this work.

\section{REFERÊNCIAS}

ANTOLINI, E. Catalysts for direct ethanol fuel cells. J. Power Sources, v. 170. p. 1-12, 2007.

ANTOLINI, E. AND GONZALEZ E. Effect of synthesis method and structural characteristics of PtSn fuel cell catalysts on the electro-oxidation of $\mathrm{CH}_{3} \mathrm{OH}$ and $\mathrm{CH}_{3} \mathrm{CH}_{2} \mathrm{OH}$ in acid medium. Catal. Today, v. 160, p. 28-38, 2011.

COLMATI, F.; ANTOLINI, E.; GONZALEZ, E. R. Pt-Sn/C electrocatalysts for methanol oxidation synthesized by reduction with formic acid. Electrochim. Acta, v. 50, p. 5496-5503, 2005.

CHRISTENSEN, P.; HAMNETT, A.; TROUGHTON, G. The role of morphology in the methanol electro-oxidation reaction. J Electroanal Chem, v 362. P. 207-218, 1993.

KAPLAN, D.; ALON, M.; BURSTEIN, L.; ROSENBERG, YU.; PELED, E. Study of core-shell platinum-based catalyst for methanol and ethylene glycol oxidation. J. Power Sources, v. 196. p. 1078-1083, 2011.

KUZNETSOV, V.; BELYI, A.; YURCHENKO, E.; SMOLIKOV, M.; PROTASOVA, M. ZATOLOKINA E.; DUPLYAKIN, V. Mössbauer spectroscopic and chemical analysis of the composition of Sn-Pt/ $\mathrm{Al}_{2} \mathrm{O}_{3}$ containing components of reforming catalyst. J Catal, v 99. p. 159-170, 1986.

STEVENS, D.; DAHN, J. Electrochemical Characterization of the Active Surface in CarbonSupported Platinum Electrocatalysts for PEM Fuel Cells. J Electrochem Soc, v150. p. A770-A775, 2003.

WANG, K.; GASTEIGER, H.; MARKOVIC, N.; ROSS, P. On the reaction pathway for methanol and carbon monoxide electrooxidation on Pt-Sn alloy versus Pt-Ru alloy surfaces. Electrochim. Acta, v. 41. p. 2587-2593, 1996. 